\title{
STUDY OF INCIDENCE AND OUTCOME OF SEPSIS IN NEPHROTIC SYNDROME
}

\author{
Mangal Charan Murmu1, Arakhita Swain² \\ ${ }^{1}$ Assistant Professor, Department of Paediatrics, SCB Medical College, Cuttack. \\ ${ }^{2}$ Associate Professor, Department of Paediatrics, SCB Medical College, Cuttack.
}

ABSTRACT

\section{BACKGROUND}

Nephrotic syndrome is a syndrome comprising signs of nephrosis, chiefly proteinuria, hypoalbuminaemia and oedema. It is a component of glomerulonephrosis in which different degrees of proteinuria occur, ${ }^{[1]}$ often associated with numerous episode of infection.

\section{MATERIALS AND METHODS}

This is a direct prospective study done in Department of Paediatrics, SCB Medical College, Cuttack from January 2015 to December 2016.

\section{RESULTS}

Minimal change nephrotic syndrome comprises of about $75 \%$ of cases of primary nephrotic syndrome and is the commonest type of nephrotic syndrome in childhood. The incidence of infectious complication is $90 \%$. Higher incidence of infection in children with frequent relapse (100\%) and steroid dependent (100\%) nephrotic syndrome.

\section{CONCLUSION}

The prevalence rate of infection in nephrotic syndrome is high in paediatric age group. Upper respiratory tract infections and urinary tract infections are more commonly encountered. The incidence of peritonitis, cellulitis and pneumonia are seen as severe sepsis.

\section{KEYWORDS}

Infection, Nephrotic Syndrome, Glucocorticoids.

HOW TO CITE THIS ARTICLE: Murmu MC, Swain A. Study of incidence and outcome of sepsis in nephrotic syndrome. J. Evolution Med. Dent. Sci. 2017;6(58):4291-4296, DOI: 10.14260/Jemds/2017/928

\begin{abstract}
BACKGROUND
Nephrotic syndrome is a common chronic disease worldwide.[1,2,3] It is characterised by alterations of permselectivity at the glomerular capillary wall, resulting in its inability to restrict the urinary loss of protein. Nephrotic range proteinuria is defined as proteinuria exceeding 1000 $\mathrm{mg} / \mathrm{m}^{2}$ per day or spot (random) urinary protein-tocreatinine ratio exceeding $2 \mathrm{mg} / \mathrm{mg}$. The proteinuria in childhood nephrotic syndrome is relatively selective, constituted primarily by albumin.[2] Estimates on the annual incidence of nephrotic syndrome range from 2 - 7 per 100,000 children and prevalence from 12 - 16 per 100,000.[3]
\end{abstract}

\section{Aims and Objectives}

To study the incidence, cause, organ involved, predisposing factors, antibiotic sensitivity of different organism seen in cases with infection in nephrotic syndrome in Paediatric Department of 1 year to 14 years.

Financial or Other, Competing Interest: None.

Submission 09-06-2017, Peer Review 08-07-2017,

Acceptance 14-07-2017, Published 20-07-2017.

Corresponding Author:

Mangal Charan Murmu,

Qr. No $-A / 4$,

Doctors Colony,

Shishu Bhawan,

Chandini Chowk,

Cuttack-753002, Odisha.

E-mail: mangal74murmu@yahoo.co.in

DOI: $10.14260 /$ jemds $/ 2017 / 928$

\section{(c) $($ ) $\$$}

\section{Place of Study}

This study was done in the Department of Paediatrics, SCB Medical College, Cuttack.

Period of Study

April 2014 to March 2016.

\section{Sample Size}

A total 200 number of cases fulfilling the inclusion criteria were taken into study.

\section{Inclusion Criteria}

Children aged 1 year to 14 years fulfilling the guidelines laid by International Study of Kidney Disease in Children (ISKDC) ${ }^{[4,5]}$ Society for Nephrotic Syndrome were included in the study.

\section{Exclusion Criteria}

Other condition present with oedema like cardiovascular disease, hepatic dysfunction, nutritional deficiency, Koch's abdomen, acute/chronic glomerulonephritis were excluded from the study with the help of allied investigations.

\section{MATERIALS AND METHODS}

This is an observational study. The children satisfying the ISKDC Society for Nephrotic Syndrome were included in the study. A detailed history was taken and clinical examination was conducted within the first day of admission and findings were noted in prescribed proforma. With the help of proper size cuff, the blood pressure was recorded in upper arm. Hypertension was defined as diastolic blood pressure more 
than $90 \mathrm{mmHg}$ in children over 6 years and more than 80 mmHg below 6 years of age.[6]

Daily fluid intake and output chart was maintained. Daily weight was recorded and change was noted in the format prescribed. Oliguria is defined as a urine output that is less than $1 \mathrm{~mL} / \mathrm{kg} / \mathrm{h}$ in infants and less than $0.5 \mathrm{~mL} / \mathrm{kg} / \mathrm{h}$ in children.[7]

\section{Associated Infection in Nephrotic Syndrome}

Nephrotic syndrome is considered to be an immunosuppressive condition and hence is associated with increased prevalence of superimposed infections. ${ }^{[8]}$ Infectious complications are common in Nephrotic Syndrome (NS), especially primary peritonitis which has been reported in $9 \%$ to $16 \%$ of patients. ${ }^{[9]}$ Steroid use may aggravate infectious complications.[10] Sepsis is a life-threatening condition that arises when the body's response to infection causes injury to its own tissues and organs.[11] The infectious conditions encountered in nephrotic syndrome in our study included are described below.

\section{Upper Respiratory Tract Infections (URI or URTI)}

All illnesses are caused by an acute infection which involves the upper respiratory tract including the nose, sinuses, pharynx or larynx. This commonly includes nasal obstruction, sore throat, tonsillitis, pharyngitis, laryngitis, sinusitis, otitis media and the common cold.[12] Most infections are viral in nature and in other instances the cause is bacterial.[13] Upper respiratory tract infections can also be fungal or helminth in origin, but these are far less common.[14]

Diagnosis of Pneumonia is being made by standard protocol of fast breathing and radiological evidence.[15]

A Urinary Tract Infection (UTI) is an infection that affects part of the urinary tract.[16] When it affects the lower urinary tract it is known as a bladder infection (cystitis) and when it affects the upper urinary tract it is known as kidney infection (pyelonephritis).[17] Symptoms from a lower urinary tract include pain with urination, frequent urination and feeling the need to urinate despite having an empty bladder.[16] Symptoms of a kidney infection include fever and flank pain, usually in addition to the symptoms of a lower UTI.[17] Rarely, the urine may appear bloody.[18] In the very old and the very young, symptoms may be vague or non-specific.[16,19]

Major infections were defined as those that are disseminated, affecting deep organs, requiring hospitalisation or potentially life-threatening, most common being peritonitis. ${ }^{[20-35]}$

Patient with nephrotic syndrome can have obvious symptoms, among which oedema is very common; and for patient with very severe condition they may even have pleural effusion, sometime empyema.

Bacterial infections are common in patients with nephrotic syndrome including peritonitis, sepsis, meningitis, urinary tract infection and cellulitis.[23]

Diarrhoea is not uncommon in Nephrotic Syndrome. [8,23]

Pyoderma and cellulitis were diagnosed clinically.

\section{Investigations}

Following investigations were done in Central Laboratory, Pathology Department, Biochemistry Department of SCB Medical College, Cuttack. I. Urine examination: Routine and Microscopic including Specific gravity, Turbidity, Reducing sugar, Albumin, Culture and Sensitivity; II. Haematological tests like Haemoglobin, Total Leucocyte Count, Differential Count, Erythrocyte Sedimentation Rate, Blood Urea, Serum Creatinine, Serum Electrolyte, Serum Cholesterol, C-Reactive Protein and Serum Total Protein; III. Diagnostic paracentesis; IV. Stool examination; V. Pus examination; VI. Mantoux test; VII. Radiological examination; VIII. CSF examination; IX. Throat swab/skin swab was done.

Standard treatment protocol were being followed[24,25,26] and observations were obtained.

\section{RESULTS}

\begin{tabular}{|c|c|c|c|}
\hline Year & Total Admission & No. of Case & Percentage \\
\hline $\begin{array}{l}\text { April } 2014 \text { - } \\
\text { March } 2015\end{array}$ & 10500 & 98 & 0.93 \\
\hline $\begin{array}{l}\text { April } 2015 \text { - } \\
\text { March } 2016\end{array}$ & 11100 & 102 & 0.91 \\
\hline Total & 21610 & 200 & 0.92 \\
\hline
\end{tabular}

The average incidence of Nephrotic syndrome is $0.92 \%$.

\begin{tabular}{|c|c|c|c|c|c|}
\hline \multirow{2}{*}{$\begin{array}{c}\text { Age Group } \\
\text { in Years }\end{array}$} & $\begin{array}{c}\text { Total } \\
\text { Number of } \\
\text { Cases }\end{array}$ & \multicolumn{2}{|c|}{ Male } & \multicolumn{2}{c|}{ Female } \\
\cline { 3 - 6 } & No & \% & No & \% \\
\hline $0-1$ & - & - & - & - & - \\
\hline $1-3$ & 72 & 51 & 70.83 & 21 & 29.17 \\
\hline $4-6$ & 68 & 42 & 61.76 & 26 & 38.24 \\
\hline $7-9$ & 32 & 23 & 71.87 & 9 & 28.13 \\
\hline $10-12$ & 16 & 10 & 62.5 & 6 & 37.5 \\
\hline $13-14$ & 12 & 9 & 75 & 3 & 25 \\
\hline Total & $\mathbf{2 0 0}$ & 135 & $\mathbf{6 7 . 5}$ & $\mathbf{6 5}$ & $\mathbf{3 2 . 5}$ \\
\hline
\end{tabular}

Table 2. Age and Sex Distributions of Nephrotic syndrome

This table shows male: female ratio of $2: 1$.

\begin{tabular}{|c|c|c|}
\hline Clinical Finding & No. of Cases & Percentage \\
\hline Pallor & 136 & 68 \\
\hline Oedema & 200 & 100 \\
\hline $\begin{array}{l}\text { Facial puffiness along } \\
\text { with pedal oedema }\end{array}$ & 174 & 87 \\
\hline 2. $\quad$ Scrotal oedema & 62 & 31 \\
\hline 3. $\quad$ Scalp oedema & 14 & 7 \\
\hline Fever & 76 & 38 \\
\hline Oliguria & 106 & 53 \\
\hline Ascites & 96 & 48 \\
\hline Frank haematuria & 22 & 11 \\
\hline Hypertension & 20 & 10 \\
\hline Convulsion & 6 & 3 \\
\hline Irritability & 56 & 28 \\
\hline Pain abdomen & 54 & 27 \\
\hline Diarrhoea & 24 & 12 \\
\hline Anorexia & 38 & 19 \\
\hline Respiratory symptoms/cough & 54 & 27 \\
\hline Skin infection & 8 & 4 \\
\hline
\end{tabular}

Most common clinical presentation of nephrotic syndrome were presence of oedema $(100 \%)$, pallor $(68 \%)$, oliguria (53\%) and ascites (48\%). 


\begin{tabular}{|c|c|c|}
\hline Associated Infections & No. of Cases & Percentage \\
\hline Skin infection & 8 & 4 \\
\hline $\begin{array}{l}\text { Upper respiratory tract } \\
\text { infection }\end{array}$ & 54 & 27 \\
\hline Urinary tract infection & 56 & 28 \\
\hline Peritonitis & 20 & 10 \\
\hline Pneumonia & 26 & 13 \\
\hline Pyogenic meningitis & 2 & 1 \\
\hline Pulmonary tuberculosis & 3 & 1.5 \\
\hline Cellulitis & 3 & 1.5 \\
\hline Gastroenteritis & 8 & 4 \\
\hline Without any infections & 20 & 10 \\
\hline \multicolumn{3}{|c|}{$\begin{array}{l}\text { Table 4. Distribution of Associated } \\
\text { Infections in Nephrotic Syndrome }\end{array}$} \\
\hline
\end{tabular}

The incidence of commonest associated infection encountered are Urinary Tract Infection, Upper Respiratory Tract Infection, Pneumonia and Peritonitis are 28\%, 27\%, $13 \%, 10 \%$ respectively.

\begin{tabular}{|c|c|c|c|c|}
\hline $\begin{array}{c}\text { Nephrotic } \\
\text { Syndrome }\end{array}$ & $\begin{array}{c}\text { No. of Cases } \\
\mathbf{n = 2 0 0}\end{array}$ & $\mathbf{\%}$ & $\begin{array}{c}\text { Associated } \\
\text { Infections }\end{array}$ & $\mathbf{\%}$ \\
\hline First attack & 64 & 32 & 52 & 80 \\
\hline $\begin{array}{c}\text { Relapse and no } \\
\text { steroid }\end{array}$ & 87 & 43.5 & 63 & 72.4 \\
\hline $\begin{array}{c}\text { Relapse with } \\
\text { steroid }\end{array}$ & 19 & 9.5 & 17 & 89.4 \\
\hline $\begin{array}{c}\text { Frequent } \\
\text { Relapse and no } \\
\text { steroid }\end{array}$ & 7 & 3.5 & 7 & 100 \\
\hline $\begin{array}{c}\text { Frequent } \\
\text { Relapse with } \\
\text { steroid }\end{array}$ & 15 & 7.5 & 15 & 100 \\
\hline $\begin{array}{c}\text { Steroid } \\
\text { dependent }\end{array}$ & 13 & 6.5 & 13 & 100 \\
\hline \multicolumn{7}{|c|}{ Table 5. Course of Nephrotic Syndrome on Admissions } \\
\hline
\end{tabular}

The table shows $32 \%$ patients were having first episode of nephrotic syndrome, of which $80 \%$ presented with infection. The episode of relapse was always associated with infections. The patient with frequent relapse and steroid dependent showed higher incidence of infections, almost $100 \%$.

\begin{tabular}{|c|c|c|c|c|c|c|c|c|c|c|c|c|c|c|c|c|c|c|}
\hline \multirow{2}{*}{$\begin{array}{l}\text { Age in } \\
\text { Years }\end{array}$} & \multicolumn{2}{|c|}{ UTI } & \multicolumn{2}{|c|}{ URTI } & \multicolumn{2}{|c|}{ LRTI } & \multicolumn{2}{|c|}{ EMPY } & \multicolumn{2}{|c|}{ PERIT } & \multicolumn{2}{|c|}{ GE } & \multicolumn{2}{|c|}{ MEN } & \multicolumn{2}{|c|}{ TB } & \multicolumn{2}{|c|}{ CELLU } \\
\hline & $\mathbf{M}$ & $\mathbf{F}$ & $\mathbf{M}$ & $\mathbf{F}$ & $\mathbf{M}$ & $\mathbf{F}$ & $\mathbf{M}$ & $\mathbf{F}$ & $\mathbf{M}$ & $\mathbf{F}$ & $\mathbf{M}$ & $\mathbf{F}$ & $\mathbf{M}$ & $\mathbf{F}$ & $\mathbf{M}$ & $\mathbf{F}$ & $\mathbf{M}$ & $\mathbf{F}$ \\
\hline $1-4$ & 11 & 7 & 9 & 8 & 5 & 2 & - & - & 2 & 1 & - & 2 & - & - & - & - & - & - \\
\hline $5-9$ & 13 & 8 & 12 & 8 & 6 & 3 & 1 & 1 & 4 & 3 & 1 & 2 & 1 & - & 1 & 1 & 2 & - \\
\hline $10-14$ & 9 & 8 & 10 & 7 & 4 & 1 & 1 & - & 6 & 4 & 2 & 1 & - & 1 & 1 & - & - & 1 \\
\hline$\%$ & \multicolumn{2}{|c|}{31.11} & \multicolumn{2}{|c|}{30} & \multicolumn{2}{|c|}{11.6} & \multicolumn{2}{|c|}{1.66} & \multicolumn{2}{|c|}{11.11} & \multicolumn{2}{|c|}{4.44} & \multicolumn{2}{|c|}{1.11} & \multicolumn{2}{|c|}{1.66} & \multicolumn{2}{|c|}{1.66} \\
\hline
\end{tabular}

Out of 180 cases presented with different infections males were 104 (57.77\%) and females were 76 (42.23\%). Most common were UTI (31.11\%), URTI (30\%), Pneumonia (11.66\%) and Peritonitis $(11.11 \%)$.

\begin{tabular}{|c|c|c|c|c|c|c|c|}
\hline Organism n=63 & $\begin{array}{c}\text { UTI } \\
\mathbf{n = 5 6}\end{array}$ & $\begin{array}{c}\text { Peritonitis } \\
\mathbf{n = 2 0}\end{array}$ & $\begin{array}{c}\text { Pneumonia } \\
\mathbf{n = 2 1}\end{array}$ & $\begin{array}{c}\text { Empyema } \\
\mathbf{n = 3}\end{array}$ & $\begin{array}{c}\text { URTI } \\
\mathbf{n = 5 4}\end{array}$ & $\begin{array}{c}\text { Meningitis } \\
\mathbf{n = 2}\end{array}$ & $\begin{array}{c}\text { GE } \\
\mathbf{n = 8}\end{array}$ \\
\hline E. coli (45) & 39 & 3 & - & - & - & - & 3 \\
\hline Kleb (4) & 2 & 1 & 1 & - & - & - & - \\
\hline Pseudomo (1) & 1 & - & - & - & - & - & - \\
\hline Proteus (1) & 1 & - & - & - & - & - & - \\
\hline GABHS (8) & - & - & - & 1 & 7 & - & - \\
\hline Staph (2) & - & - & 2 & - & - & - & - \\
\hline Pneumo (2) & - & 2 & - & - & - & - & - \\
\hline Mixed (1) & 1 & - & - & - & - & - & - \\
\hline No organism & 12 & 14 & 18 & 2 & 47 & 2 & 5 \\
\hline Percentage & 78.5 & 30 & 14.28 & 33.33 & 12.96 & 0 & 37.5 \\
\hline & \multicolumn{7}{r}{ Table 7. Organism in Different Infections in Nephrotic Syndrome } \\
\hline
\end{tabular}

Significant number of culture positive were found in patients with UTI (69.84\%). The culture were negative in meningitis, low in URTI (12.96\%), Pneumonia (14.28\%) and peritonitis (30\%).

\begin{tabular}{|c|c|c|c|c|c|c|c|c|c|c|c|c|c|c|c|c|c|}
\hline \multirow{2}{*}{$\begin{array}{c}\begin{array}{c}\text { Organism } \\
\text { Isolated }\end{array} \\
\text { E. coli }\end{array}$} & \multirow{2}{*}{$\begin{array}{c}\begin{array}{c}\text { No. of } \\
\text { Cases }\end{array} \\
45 \\
\end{array}$} & \multicolumn{2}{|c|}{ Ampi/\% } & \multicolumn{2}{|c|}{ Amika/\% } & \multicolumn{2}{|c|}{ Netro/\% } & \multicolumn{2}{|c|}{ Nitro/\% } & \multicolumn{2}{|c|}{ Cefo/\% } & \multicolumn{2}{|c|}{ Norf/\% } & \multicolumn{2}{|c|}{ Vanco/\% } & \multicolumn{2}{|c|}{ Chlora/\% } \\
\hline & & 9 & 20 & 34 & 75 & 7 & 15 & 9 & 45 & 32 & 50 & 6 & 13 & 4 & 8 & 2 & 4 \\
\hline Proteus & 1 & 4 & 4 & 2 & 2 & 2 & 2 & 4 & 4 & 1 & 100 & - & - & 4 & 4 & - & - \\
\hline Klebsiella & 4 & - & - & 2 & 50 & 1 & 25 & - & - & 3 & 75 & - & - & 2 & 50 & - & - \\
\hline Pseudo & 1 & - & - & 1 & 100 & - & - & - & - & 1 & 100 & 1 & 100 & - & - & - & - \\
\hline GABHS & 8 & 5 & 62 & 6 & 75 & - & - & - & - & 6 & 75 & - & - & - & - & - & - \\
\hline Pneum. & 2 & - & - & - & - & - & - & - & - & 2 & 100 & - & - & - & - & 2 & 100 \\
\hline Staph. & 2 & 2 & 100 & 2 & 100 & - & - & - & - & 2 & 100 & - & - & 2 & 100 & - & - \\
\hline Mixed & 1 & 1 & 100 & 1 & 100 & 1 & 100 & - & - & - & - & - & - & 1 & 100 & - & - \\
\hline Total & 64 & 21 & 32 & 48 & 75 & 11 & 17 & 13 & 20 & 47 & 73 & 7 & 10 & 13 & 20 & 4 & 6 \\
\hline
\end{tabular}


The most sensitive drugs against all the infection was amikacin followed by cefotaxime. The organism isolated E. coli was sensitive to amikacin, cefotaxime, ampicillin, nitrofurantoin and netromycin in order. Pneumococcus isolated from peritoneal fluid culture is sensitive to Vancomycin.

\begin{tabular}{|c|c|c|c|c|c|}
\hline \multicolumn{6}{|c|}{ Response after 10 days of Treatment } \\
\hline Drugs Used & 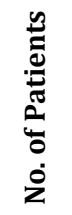 & $\begin{array}{l}\text { Improvement } \\
\text { (Clinical and } \\
\text { Laboratory) }\end{array}$ & $\%$ & 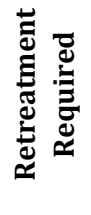 & $\%$ \\
\hline Ampicillin & 27 & 27 & 100 & No & - \\
\hline Amikacin & 76 & 76 & 100 & No & - \\
\hline Netromycin & 9 & 9 & 100 & No & - \\
\hline Nitrofurantoin & 2 & 2 & 100 & 2 & 100 \\
\hline Cefotaxime & 62 & 62 & 100 & No & - \\
\hline Chloramphenicol & 1 & 1 & 100 & No & - \\
\hline Vancomycin & 3 & 3 & 100 & No & - \\
\hline Total & 180 & 180 & & 2 & \\
\hline
\end{tabular}

There was significant improvement clinically and laboratory investigation wise except two cases of nitrofurantoin.

\begin{tabular}{|c|c|c|c|c|}
\hline Infections & $\begin{array}{l}\text { No. of } \\
\text { Cases }\end{array}$ & $\begin{array}{l}\text { Nephrotic } \\
\text { State }\end{array}$ & $\begin{array}{l}\text { No. of } \\
\text { Cases }\end{array}$ & $\%$ \\
\hline \multirow{2}{*}{ URTI } & \multirow{2}{*}{54} & SD & 6 & 11.11 \\
\hline & & SR & 7 & 12.96 \\
\hline \multirow{2}{*}{ UTI } & \multirow{2}{*}{56} & SD & 7 & 12.5 \\
\hline & & SR & 8 & 14.28 \\
\hline LRTI & 26 & - & - & - \\
\hline Peritonitis & 20 & - & - & - \\
\hline Cellulitis & 3 & - & - & - \\
\hline Meningitis & 2 & - & - & - \\
\hline PTB & 3 & - & - & - \\
\hline $\mathrm{GE}$ & 8 & SR & 1 & 12.5 \\
\hline Septicaemia & 2 & Death & 2 & - \\
\hline Skin Infection & 6 & - & - & - \\
\hline Without INF & 20 & - & - & - \\
\hline TOTAL & 200 & & 16 & 8 \\
\hline
\end{tabular}

Spontaneous remission rate was $10 \%$. Rest of the patients were treated with glucocorticoid. Two patients who died (1\%) after admission and on treatment for frequent relapse case of Nephrotic Syndrome were found to have septicaemia.

\section{DISCUSSION}

The primary or idiopathic nephrotic syndrome, majority of which are histopathologically classified as Minimal Change Nephrotic Syndrome (MCNS). MCNS comprises about 75\% of cases of nephrotic syndrome and is the most common type of nephrotic syndrome.[27]

We encountered that $92 \%$ admissions of every year were Nephrotic Syndrome. Eddy AA et al estimates on the annual incidence of nephrotic syndrome range from 2 - 7 per 100,000 children and prevalence from $12-16$ per
$100,000 .[2,3]$ The incidence of NS as reported by Schlesinger et al in 1968 is 1.3 to 2.8 per one lakh white children under 16 years.[28] Our study shows little higher rate of incidence.

$70 \%$ of NS were encountered in the age group of $1-6$ years with peak incidence of cases in 1 - 3 years' age period. Males are predominant over females in the present study. The present observation is in accordance with the study made by Heymann, Marker et al 1972,[27] Agarwal et al 1975[29] and Srivastava et al 1975.[30]

The most common clinical presentation of nephrotic syndrome were presence of oedema $(100 \%)$, pallor $(68 \%)$, oliguria (53\%) and ascites (48\%). Cases of anuria, frank haematuria, hypertension and convulsion were observed in 6 (3\%) cases $5(2.5 \%)$ cases and $1(0.5 \%)$ case respectively. Similar type of finding has been documented by Agarwal et al 1975[29] and Srivastav et al 1975.[30]

The percentage of the commonest associated infections encountered are Urinary Tract Infection, Upper Respiratory Tract Infection, Pneumonia and Peritonitis are 28\%, 27\%, $13 \%$ and $10 \%$ respectively. The study was done by Brod et al 1973[31] and Rubin 1975. It also is in agreement with the report from Children's Hospital, Sao Paulo, Brazil and Noorani et al 2003 and Alwadhi RK et al 2004.[32]

$32 \%$ patients were having first episode of nephrotic syndrome, of which $80 \%$ presented with infection. The episode of relapse was always associated with infections. The patient with frequent relapse and steroid dependent showed higher incidence of infections, almost $100 \%$.

Out of 180 cases presented with different infections males were $104(57.77 \%)$ and females were 76 (42.23\%). Most cases of culture were negative in URTI (87\%), Pneumonia $(85 \%)$ and peritonitis (87\%). Significant number of culture positive were found in patients with UTI $(78.5 \%)$. The most sensitive drugs against all the infections was amikacin followed by cefotaxime. The organism isolated $\mathrm{E}$. coli was sensitive to amikacin, cefotaxime, ampicillin, nitrofurantoin and netromycin in order. Pneumococcus isolated from peritoneal fluid culture is sensitive to Vancomycin. The other organisms were Klebsiella (4\%), GABHS (12\%) and mixed growth. Gulati S and Kher V et al $1995\left[{ }^{[9]}\right.$ found $61 \%$ of culture isolates were E. coli and non-E. coli organism.

Spontaneous remission rate was $10 \%$. Rest of the patients were treated with glucocorticoid. Two $(1.11 \%)$ patients who died after admission were on treatment for frequent relapse case of Nephrotic Syndrome were found to have septicaemia. Lewis et al[33] studying the natural history of disease before the introduction of glucocorticoids found that in $25 \%$ cases with control of infection remission occurs within 15 days. Wingen et al[34] in their study concluded that delay up to 10 days in stating steroid therapy did not adversely influence the further course of this or subsequent relapse in the absence of progressive clinical signs.

\section{Summary}

The overall incidence of hospital admission of nephrotic syndrome was $0.92 \%$. The most vulnerable group was $1-6$ years. Male overscore female. Oedema was the most prominent clinical features followed by Haematuria and Hypertension. Infections were found in $90 \%$ cases of nephrotic syndrome. The most common associated infections causing sepsis were URI, UTI, LRTI and Peritonitis respectively. Cellulitis, gastroenteritis, meningitis and 
tuberculosis do occur, but less in number. $75 \%$ of the infections were present with $1^{\text {st }}, 2^{\text {nd }}$ or $3^{\text {rd }}$ relapse and $25 \%$ cases occurred in $1^{\text {st }}$ episode of NS. E. coli was the commonest organism isolated. Amikacin was effective in 63.6\%, Norfloxacin in $45.4 \%$ and Cefotaxime in $45.5 \%$ of organism. E. coli was sensitive to following drugs in order of Cefotaxime, Amikacin, Norfloxacin, Ciprofloxacin, Ampicillin, Nitrofurantoin, Netromycin and Chloramphenicol. Overall, gram negative organisms were predominant cause of different infections. All the causes had effective therapeutic response to their sensitive drugs within 10 days of treatment except for one case who did not respond to Nitrofurantoin. $7 \%$ children had spontaneous remission when infection was treated without requiring glucocorticoids. Death due to sepsis in nephrotic syndrome in our study is $1.11 \%$; $13.9 \%$ people per 100,000 population died from nephritis, nephrotic syndrome and nephrosis each year in the US 2001 (Deaths: Final Data for 2001, NCHS, CDC).

\section{CONCLUSION}

Infection is more common in male baby as compared to girl baby in between 1 and 5 years' age group. Upper respiratory tract infection and urinary tract infections are more common and are usually associated with relapse. Infections are more common with frequent relapse, steroid dependent nephrotic syndrome. UTI is an important occult infection, which is often underdiagnosed. Peritonitis cellulitis and pneumonia are most serious infections. Infections with gram negative organism are emerging, a combination of antibiotics covering pneumococcus and gram-negative organisms should be started empirically according to the sensitivity pattern. In our study, we set up a combination of ampicillin and cefotaxime. Therapy should be tailored according to the culture and sensitivity report. In serious life-threatening case, vancomycin is lifesaving. Immunosuppression resulting from glucocorticoid therapy may make the child more susceptible to develop serious infection, but as per our study even children who are not on glucocorticoid therapy presenting with relapse often have concomitant infection. As a chronic disease with high morbidity, prevention of infection in nephrotic syndrome children need consideration. Relapse is more often due to infections. The best way to control the nephrotic state is to prevent infection.

$\begin{array}{ll}\text { Abbreviations } \\ \text { A: G: } & \text { Albumin: Globulin. } \\ \text { AGN: } & \text { Acute Glomerulonephritis. } \\ \text { BP: } & \text { Blood Pressure. } \\ \text { CNS: } & \text { Central Nervous System. } \\ \text { DC: } & \text { Differential Count. } \\ \text { E. coli: } & \text { Escherichia coli. } \\ \text { ESR: } & \text { Erythrocyte Sedimentation Rate. } \\ \text { Exam: } & \text { Examination. } \\ \text { FR: } & \text { Frequent Relapse. } \\ \text { GI: } & \text { Gastrointestinal. } \\ \text { GE: } & \text { Gastroenteritis. } \\ \text { Gp: } & \text { Group. } \\ \text { Hb: } & \text { Haemoglobin. } \\ \text { Ig: } & \text { Immunoglobulin. } \\ \text { Inf: } & \text { Infection. } \\ \text { Kleb: } & \text { Klebsiella. } \\ \text { KUB: } & \text { Kidney Ureter Bladder. }\end{array}$

LRTI: Lower Respiratory Tract Infections.

No: Number.

NS: $\quad$ Nephrotic Syndrome.

Perito: Peritonitis.

PTB: Pulmonary Tuberculosis.

Prim: Primary.

Syn: Syndrome.

R: $\quad$ Relapse.

RBC: $\quad$ Red Blood Cell.

RR: $\quad$ Respiration Rate.

SD: $\quad$ Steroid Dependent.

SR: Spontaneous Remission.

TLC: Total Leucocyte Count.

URTI: Upper Respiratory Tract Infections.

UTI: Urinary Tract Infection.

USG: Ultrasonography.

WBC: White Blood Cell.

\section{REFERENCES}

[1] Dunphy LM. In classic forms of glomerulonephrosis, nephrotic syndrome develops, and various degrees of proteinuria may be present. In addition to hypertension, other characteristic findings include hypercholesterolemia with lipiduria and central edema from hypoalbuminemia due to albuminuria. Winland-Brown, Jill; Porter, Brian; Thomas, Debera. Primary Care. F.A. Davis 2015:P 634.

[2] Bagga A, Mantan M. Nephrotic syndrome in children. Indian J Med Res 2005;122(1):13-28.

[3] Eddy AA, Symons JM. Nephrotic syndrome in childhood. Lancet 2003;362(9384):629-39.

[4] Nephrotic syndrome in children: prediction of histopathology from clinical and laboratory characteristics at time of diagnosis. A report of the international study of kidney disease in children. Kidney Int 1978;13(2):159-65.

[5] The primary nephrotic syndrome in children. Identification of patients with minimal change nephrotic syndrome from initial response to prednisone. J Pediatr 1981;98(4):561-4.

[6] Srivastava RN, Mayekar G, Anand R, et al. Nephrotic syndrome in Indian children. Arch Dis Child 1975;50(8):626-30.

[7] Devarajan P. Acute kidney injury: acute kidney injury: still misunderstood and misdiagnosed. Nat Rev Nephrol 2017;13(3):137-8.

[8] Jain A, Malhotra S, Das A, et al. Candida diarrhoea in a patient of nephrotic syndrome. Journal of case report 2014.

[9] Gulati S, Kher V, Gupta A, et al. Spectrum of infections in Indian children with nephrotic syndrome. Pediatric Nephrology 1995;9(4):431-4.

[10] Matsell DG, Wyatt RJ. The role of I and B in peritonitis associated with the nephrotic syndrome of childhood. Pediatr Res 1993;34:84-8.

[11] Singer M, Deutschman CS, Seymour CW, et al. The third international consensus definitions for sepsis and septic shock (sepsis-3). JAMA 2016;315(8): 801-10.

[12] Mieczyslaw P. Pulmonary infection. Cham: Springer. 2015. 
[13] Rosenstein N, Phillips WR, Gerber MA, et al. The common cold-principles of judicious use of antimicrobial agents. Pediatrics 1998;101(1):181-4.

[14] David H. Control of communicable diseases manual: an official report of the American public health association. APHA Press, the American Public Health Association 2015.

[15] Shah S, Bachur R, Kim D, et al. Lack of predictive value of tachypnea in the diagnosis of pneumonia in children. Pediatr Infect Dis J 2010;29(5):406-9.

[16] Adedoyin OT, Ojuawo IA, Odimayo MS, et al. Urinary tract infections in children with primary nephrotic syndrome and acute glomerulonephritis. WAJM 2010;29(4):235-8.

[17] Lane DR, Takhar SS. Diagnosis and management of urinary tract infection and pyelonephritis. Emergency medicine clinics of North America 2011;29(3):539-52.

[18] Salvatore S, Salvatore S, Cattoni E, et al. Urinary tract infections in women. European journal of obstetrics, gynecology, and reproductive biology 2011;156(2):131-6.

[19] Woodford HJ, George J. Diagnosis and management of urinary infections in older people. Clinical Medicine London 2011;11(1):80-3.

[20] Ajayan P, Krishnamurthy S, Biswal N, et al. Clinical spectrum and predictive risk factors of major infections in hospitalized children with nephrotic syndrome. Indian Pediatr 2013;50:779-81.

[21] Teo S, Walker A, Steer A. Spontaneous bacterial peritonitis as a presenting feature of nephrotic syndrome. J Paediatr Child Health 2013;49(12):106971.

[22] Uncu N, Bülbül M, Yildiz N, et al. Primary peritonitis in children with nephrotic syndrome: results of a 5-year multicenter study. Eur J Pediatr 2010;169(1):73-6.
[23] Naser M. Pneumococcal sepsis, peritonitis, and cellulitis at the first episode of nephrotic syndrome. Iranian Journal of Kidney Diseases 2013;7(5):404-6.

[24] Bomback AS, Tumlin JA, Baranski J, et al. Treatment of nephrotic syndrome with adrenocorticotropic hormone (ACTH) gel. Drug Des Devel Ther 2011;5:147-53.

[25] Gipson DS, Troost JP, Lafayette RA, et al. Complete remission in the nephrotic syndrome study network. Clin J Am Soc Nephrol 2016;11(1):81-9.

[26] Roberti I, Vyas S. Long-term outcome of children with steroid-resistant nephrotic syndrome treated with tacrolimus. Pediatr Nephrol 2010;25:1117-24.

[27] Heymann W, Lund HZ. Nephrotic syndrome in rats. Pediatrics 1951;7(5):691-706.

[28] Schlesinger ER, Sultz HA, Mosher WE, et al. The nephrotic syndrome. Its incidence and implications for the community. Am J Dis Child 1968;116(6):623-32.

[29] Choudhry VP, Agarwal R. Urinary tract infection in children. Indian Pediatr 1977;14(10):849-53.

[30] Srivastava RN. Pediatric renal problems in India. Pediatr Nephrol 1987;1(2):238-44.

[31] Brod J. The kidney. Neph synd 1973:298.

[32] Alwadhi RK, Mathew JL, Rath B. Clinical profile of children with nephrotic syndrome not on glucocorticoid therapy, but presenting with infection. J Paediatr Child Health 2004;40(1-2):28-32.

[33] Barness LA, Moll GH, Janeway CA. Nephrotic syndrome. Natural History of the Disease Pediatric 1950;5(3):486.

[34] Wingen AM, Muller-Wiefel DE, Scharer K. Spontaneous remissions in frequently relapsing and steroid dependent idiopathic nephrotic syndrome. Clin Nephrol 1985;23(1):35-40.

[35] Hingorani SR, Weiss NS, Watkins SL. Predictors of peritonitis in children with nephrotic syndrome. Pediatr Nephrol 2002;17(8):678-82. 